\title{
PRESENT-DAY CHANGES IN THE MORPHOLOGY OF THE SHORE ZONE IN THE CONDITIONS OF HEAVY TOURIST USE: THE CASE OF LAKE CZARNE (UPPER PARSĘTA CATCHMENT)
}

\author{
Mazgorzata CichoŃ \\ Institute of Geoecology and Geoinformation, Adam Mickiewicz University, Poznań, Poland
}

Manuscript received: May 18, 2011

Revised version: Septemeber 5, 2011

\begin{abstract}
Cichoń M., 2011. Present-day changes in the morphology of the shore zone in the conditions of heavy tourist use: the case of Lake Czarne (upper Parsęta catchment). Quaestiones Geographicae 30(3), Bogucki Wydawnictwo Naukowe, Poznań, pp. 5-12, 3 Figs. ISBN 978-83-62662-75-3. ISSN 0137-477X. DOI 10.2478/v10117-011-0022-0

ABSTRACT. So far, works on the effect of tourist use on relief have usually focused on mountain areas. Research confirms that changes in montane geoecosystems are not always a natural manifestation of landscape evolution, but often result from poorer resistance to degradation caused by heavy tourist traffic. In spite of a great number of studies concerning this problem, few address the effect of tourists on the geographical environment of lakeland areas. Hence, Lake Czarne was selected to determine the dynamics of morphogenetic changes in its shore area, especially in the scarp zone, with the help of geodetic surveys and studies of tourist capacity conducted in the years 2006-2009. On the basis of observations and the research, four stages in the evolution of the shore zone of Lake Czarne were distinguished that were correlated with specific meteorological and hydrological conditions affecting the number of recreationists on the beach.
\end{abstract}

KEYWORDS: changes in the morphology, shore zone of lake, tourist use, geodetic surveys

Cichoń M., Institute of Geoecology and Geoinformation, Adam Mickiewicz University, 61-680 Poznań, Poland, e-mail: cichon@amu.edu.pl

\section{Introduction}

Lake geoecosystems, which are spatial units varying in size and internal structure, keep changing both in space and time. The changes are holistic as a rule, but they usually proceed via modification of individual elements of the structure of the system. Physical, chemical and biological impacts of tourist use lead to a degradation of the natural environment of the lake and its surroundings. In the landscape of lakes, the most readily visible are changes in relief.

Studies of the effect of tourism on relief are mainly conducted in mountain areas and focus primarily on the impact of the particular forms of tourism. In the mountains, human impact is usually restricted to the width of the tourist trail, hence the research largely deals with hiking (Gorczyca 2004; Styperek 2001, Tomczyk \& Ewertowski 2007), skiing (Łajczak 1996, Skawiński \& Krzan 1996), mountaineering (Balon 1981), and cycling (Jodłowski 2001). Tourism-derived changes in the natural environment are studied with the help of a variety of methods, including geomorphological mapping, geodetic surveys, aerial photos, and direct observation combined with photography. Buchwał (2009) carried out her research of the dynamics of erosional-denu- 
dation processes on Mount Babia using the dendrogeomorphological method.

While there are many publications addressing the effect of tourist use on relief, it is only rarely that this problem is tackled in lakeland areas, and even more rarely in the lakeshore zones. The first works in this field were those by Bartkowski (1985), Dysarz (1993) Drzewiecki (1997) and Sołowiej et al. (1997). In western Europe works on the lakeshore zones, especially those suffering the human impact, are much more numerous, but they deal with large water bodies. In the foreign literature the focus is on the threat of degradation of lakeshore zones and on new approaches to shore monitoring (Ryhänen 2001, Ostendorp 2004, Schmieder 1996).

In Poland, the problems addressed in studies of lakeshore zones conducted to date have mainly been the identification and parametrisation of geomorphological processes, characteristics of shore forms, and the evolution of the littoral. It has been found that the pattern, and especially the range and intensity of shore processes producing morphological changes in the littoral zone of a water body depend on many factors. The most important include its relief and exposure, depth and size, waving, lithology, vegetation, ice cover, and surface alimentation (Korolec 1968, Drwal, Gołębiewski 1968, Banach 1993, Rzętała 1994, Nowaczyk 1994, Jaguś 2004, Grobelska 2002). A survey of the literature on changes in lacustrine geoecosystems shows that the least attention has been devoted to the role of man-made factors, especially tourism and recreation.

Changes in the geographical environment induced by tourist use depend on both, the aggressiveness of the forms of tourism pursued in the given area and the resistance of the environment to human impact. Susceptibility of lake geoecosystems depends largely on the geological structure of the slopes and the morphology of the shore zone.

The research carried out by Klimko (1982) in Wielkopolska shows that what is primarily responsible for changes in slope morphology is its inclination angle. Studies of denudation processes have revealed significant differences in the efficiency of slope processes depending on lithological differences. The scope of change was greater on surfaces built of loam rather than sand depos- its. In the opinion of Starkel (2008), the exceeding of threshold values of various processes is closely connected with the lithology of covers which separate precipitation water into overland flow, subsurface flow, and the deeper groundwater flow. However, the initiation of cover movement and the magnitude of cover shifts are associated with land use. According to Kostrzewski (2008), the performance of lake geoecosystems is controlled by weather conditions of the temperate zone. That is why an important problem in the operation of the present-day denudation system in postglacial areas is the effect of catastrophic processes on it (Kostrzewski et al. 1992).

When the resistance threshold has been surpassed, there appear specific patterns of energy flow and matter cycle, usually unique to the moment of observation (Kostrzewski 1999). A description of extreme meteorological, hydrological and geomorphological characteristics of lakeland areas was presented by Zwoliński (2008) in a special issue of the journal Landform Analysis (Florek 2008) entitled Role of extreme processes in relief formation. In most of the articles it was emphasised that of special significance for relief evolution were extreme events, mainly torrential rains. Precipitation of great intensity and frequency releases high potential energy, thus initiating largescale denudation processes resulting, as Balon et al. (2001) claim, in upsetting the equilibrium and a jump in the development of the environment of some areas. Morphogenetic changes in shore zones, however, are usually connected with the seasonal variations in weather conditions, mainly the pattern of precipitation and air temperature, and with seasonal vegetation growth. Those factors directly control the rate of relief-forming processes. Hence a research into the effect of tourist use on lakeshore zones should combine meteorological observations with a study of recreation carrying capacity. Tourist capacity (or tourist carrying capacity) is the maximum number of persons making use of the recreational assets of a site without an unacceptable degree of deterioration of the character and quality of the recreation experience (Baud-Bovy 1977, Prato 2001). Surpassing the threshold of tourist capacity produces a variety of effects. It can bring about changes in the natural resources of the site, especially its plant cover (Brown et al. 1997). 


\section{Study methods and area}

In order to determine the retreat rate of the shore scarp of Lake Czarne as a result of tourist use under different weather conditions, in the years 2006-2009 geodetic surveys were made as well as studies of the tourist capacity of selected water bodies in Central Pomerania. The studies were supplemented with data obtained from the Geoecological Station at Storkowo. To examine morphological changes in the lakeshore zone induced by various tourist uses, Lake Czarne in the upper Parsęta catchment was chosen as the object of study.

Lake Czarne and its catchment are situated on the northern slope of the end-morainic series of the Pomeranian Stage of the Vistulian glaciation (Karczewski 1989). The catchment occupies an outwash surface built of sandy fluvioglacial deposits. Lake Czarne, the only water body within the upper Parsęta catchment, is a basin without an outlet ( $3.1 \mathrm{ha}$ ) located in a watershed zone. In genetic terms, the lake is a melt-out basin with the slopes descending steeply towards the bottom and hence with a very narrow littoral zone along the shore. The shore zone studied is located in the south-eastern part of the lake catchment.

From the point of view of recreationists, a vital feature of a catchment is its lake percentage. For the upper Parsęta this figure amounts to a mere $0.38 \%$, and the lake under study is the only water body within a radius of a few kilometres. During vacations and in fine weather conditions, Lake Czarne suffers intensive human (tourist) impact, mostly linear and surficial. A single lake within a radius of a few kilometres, not more than 4 ha in area and surrounded by arable fields and pine woodland, turns out to be the only recreational possibility for the local community. Local residents use sandy and grassy areas, undeveloped in any way. There is no basic infrastructure: no access road, no sanitary facilities, sometimes even no litterbins. Mass uncontrolled tourist traffic of more than 10 persons/ha/day flows along various routes, often across low-capacity plant communities like alder carrs or riverside carrs, for which the index amounts to a few persons/ha/ day, while the number of afternoon visitors exceeds 50 per $100 \mathrm{~m}^{2}$. With the low lake percentage of the catchment and the very small area avail- able for sunbathing, in July 2006 there were 1.8 $\mathrm{m}^{2}$ of beach per person in the shore zone of Lake Czarne (Cichon 2008). This means that the capacity index for undeveloped water bodies, $12.5 \mathrm{~m}^{2} /$ person on average, was surpassed several times (Baranowska-Janota 1998). With the threshold value put by Zwoliński (1992) at $20 \mathrm{~m}^{2}$ /person, this is indicative of advancing devastation of the shore zone of the lake.

\section{Results}

On the basis of the observations and geodetic surveys conducted, stages in the evolution of the shore zone of Lake Czarne were distinguished that were correlated with the meteorological and hydrological conditions determining the intensity of denudation processes and the use of the water body for recreational purposes (Fig. 1).

The first dissections and very shallow landslips caused by a small group of recreationists were observed early in July 2006 (Fig. 2a). A surficial slip of wet material about $20 \mathrm{~cm}$ in width (after a fall of rain on 21 June 2006) was only observed in the scarp zone. From mid-July 2006, maximum temperatures recorded in Central Pomerania exceeded $30^{\circ} \mathrm{C}$, resulting in each square metre of the beach being occupied by an inadmissibly large group of recreationists. However, the surpassing of tourist capacity (with $1.8 \mathrm{~m}^{2}$ of beach per person) in the shore zone (Cichon 2008) did not affect its relief owing to the stable soil structure. A high, even extremely high, temperature in excess of $30^{\circ} \mathrm{C}$ and low soil moisture had caused the soil to dry and harden, thus making it much

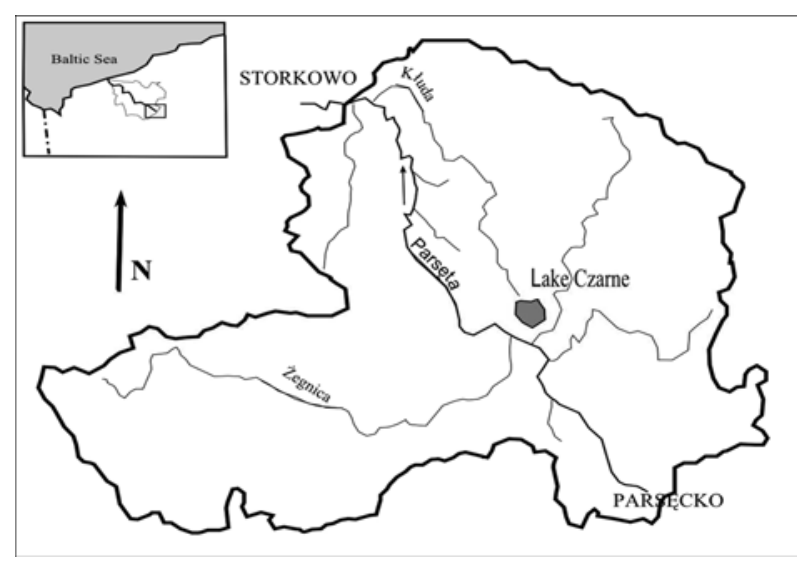

Fig. 1. Location of Lake Czarne. 

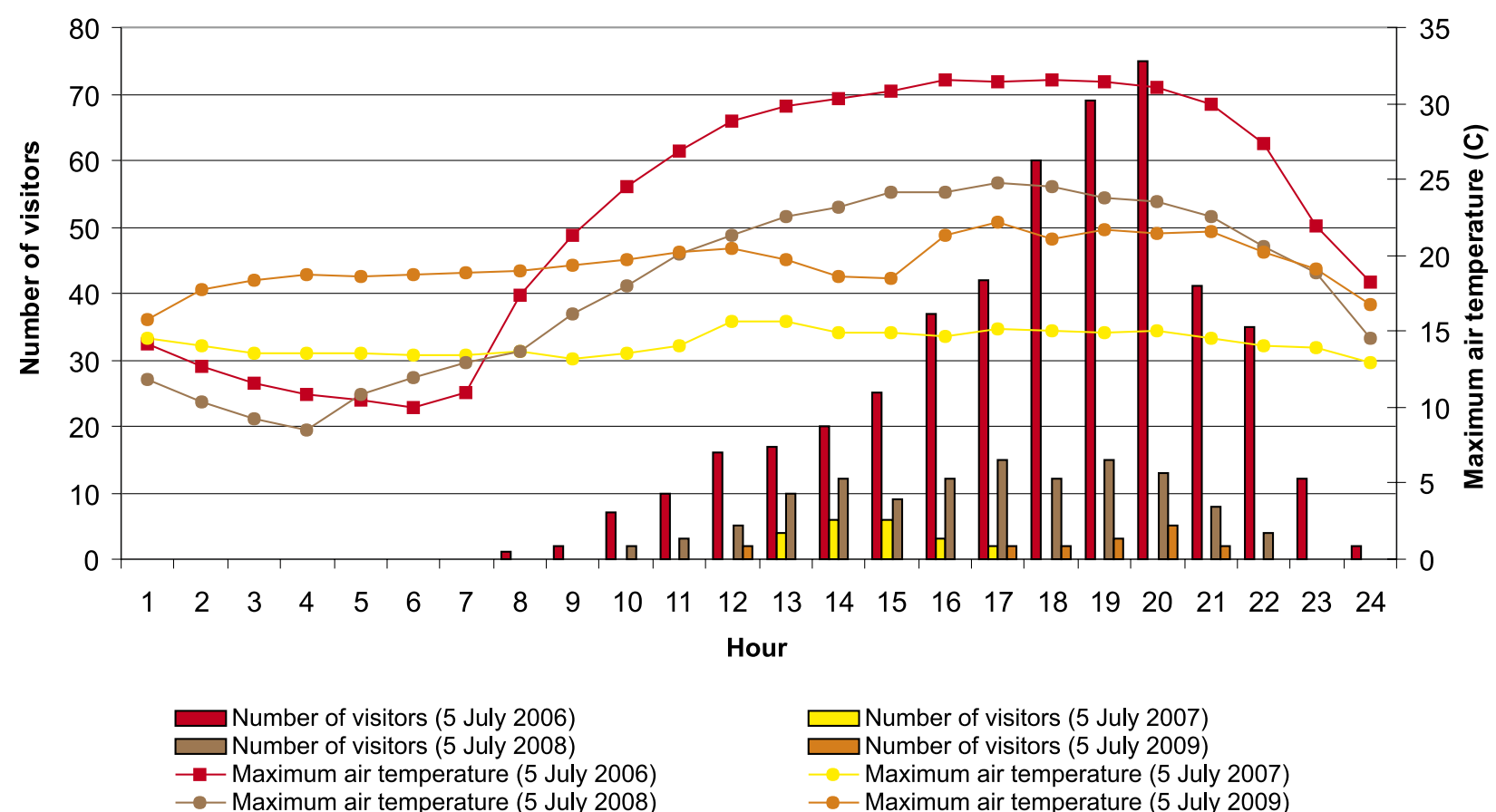

Fig. 2. Distribution of air temperatures on 5 July in the years 2006-2009 and the number of visitors in the shore zone of Lake Czarne.

less susceptible to denudation. In turn, in August the temperature oscillated around $20^{\circ} \mathrm{C}$ and it rained almost every day ( $2 \mathrm{~mm} /$ day on average). Such a meteorological situation did not encourage visits, but on the other hand the presence on the beach of even a few persons caused shifts in the material which daily rains had made wet and hence more plastic. Susceptibility to denudation grew in mid-September when after a long period of precipitation the temperature rose above $20^{\circ} \mathrm{C}$, which produced an increase in the number of people visiting the beach for recreational purposes. With an increase in the plasticity of the material and the number of beach visitors, the microforms in the scarp zone expanded. The erosional dissection developed into a small erosional niche, with the slipped material accumulating at its foot. It might be mentioned here that at the start of the summer season sand had been dumped on the shore, and its observation in the successive years helped to record changes in the shape of the lake terrace.

The next summer season was completely different from the previous year in meteorological terms. June and most of July 2007 brought waves of rain, several times exceeding $20 \mathrm{~mm} /$ day, while diurnal air temperatures only amounted to $15-20^{\circ} \mathrm{C}$. This caused the water level in the lake to rise, which resulted in the wash-out of material deposited at the foot of the scarp. The high water stage persisting until the end of July undercut the shore. Decisive for changes in the morphology of the shore zone, especially its scarp, was the period from 15 to 21 July with no precipitation and the maximum air temperature at noon exceeding $25^{\circ} \mathrm{C}$. Such a weather situation attracted recreationists to the beach, where each passage of a visitor on the wet soil, mostly in the scarp zone, left a trace and produced increasingly large microforms. The effect was a trodden path visible in Fig. 2b, photographed on 21 July 2007. The beginning of August was dry, but the diurnal air temperature oscillating around $15^{\circ} \mathrm{C}$ did not encourage sunbathing. The rest of August was wet, although rainfall did not surpass $2 \mathrm{~mm} /$ day. There were also rainless days, but a maximum temperature of about $20^{\circ} \mathrm{C}$ and very wet soil heavily reduced visitor frequency. There was a marked deterioration in September weather: the diurnal temperature ranged from 8 to $13^{\circ} \mathrm{C}$ and the rain continued. Changes in the morphology of the shore zone in that part of the summer season were slight, owing to the disagreeable local meteorological situation and a small number of visitors. The microforms that developed during that season were due to a sudden jump in 
I STAGE \& II STAGE

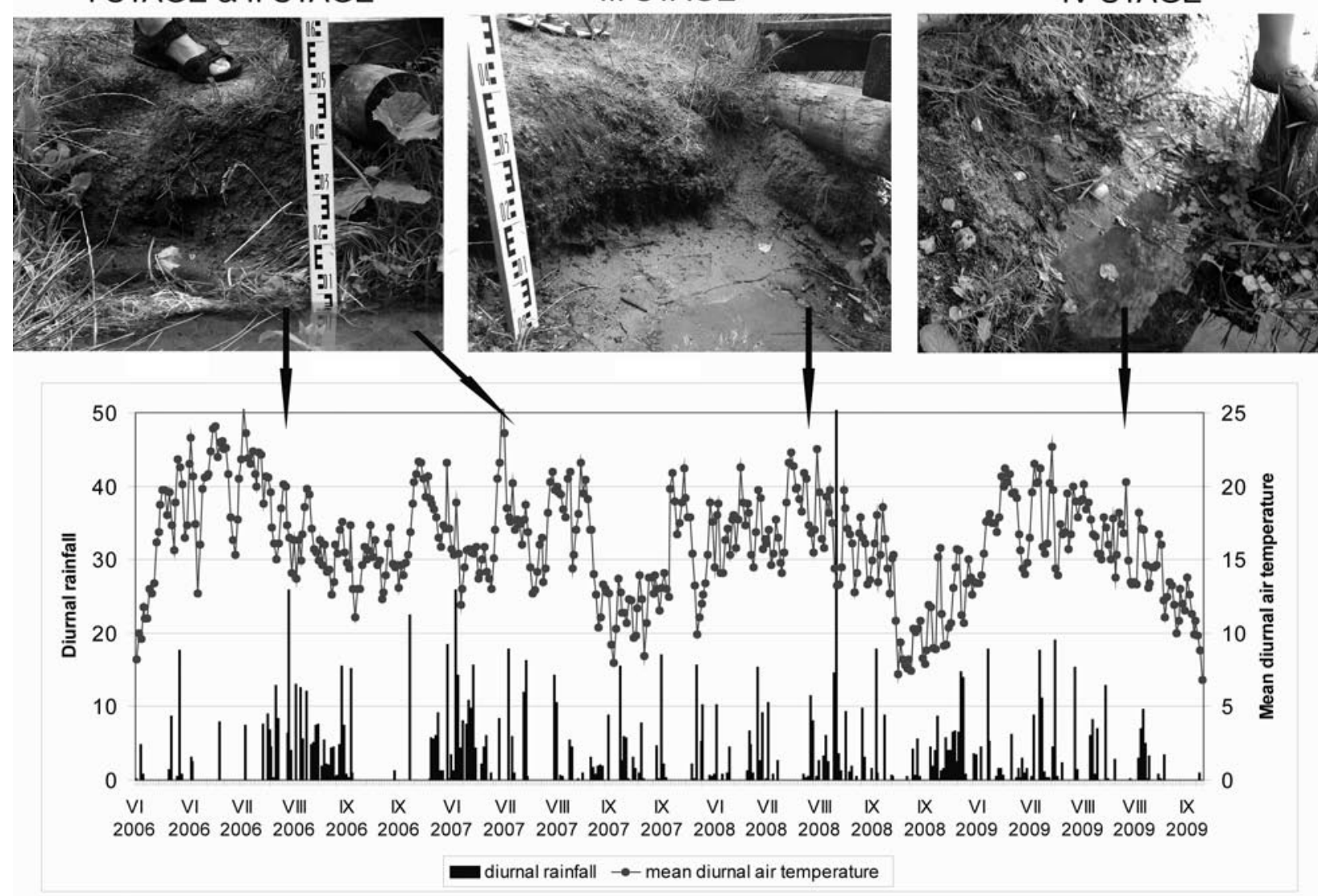

Fig. 3. Morphological changes in the shore zone of Lake Czarne and the meteorological situation in the upper Parsęta catchment.

temperature and an increase in the number of recreationists on the beach in conditions favourable to material slipping (a surface layer parched and underlain by a plastic sand-loam layer) and a persistently high stage of the lake waters. A big role in blocking morphogenetic changes in the summer season of 2007 was played by vegetation, which had perfect conditions for growth owing to ample precipitation already from spring.

The summer season of 2008, especially June and July, showed variations in the intensity of morphogenetic processes in the shore zone of Lake Czarne. Dry periods with exceptionally high temperatures (1-10 June and 21-31 July) and only slight modelling of the shore alternated with short but fierce rainstorms (11-30 June, 6-20 July, and the whole of August) resulting in accelerated development of microforms. The erosional niche that appeared in the scarp zone at the start of July 2008 grew systematically to reach $80 \mathrm{~cm}$ in length, $70 \mathrm{~cm}$ in width, and $40 \mathrm{~cm}$ in height at the close of August (Fig. 2c). The chief process responsible for those changes was sliding, and during heavy rains, wash. Equally important for the development of the shore zone were the lake waters. Through their erosional action during high stages the shore was being undercut, and the very wet material of the scarp zone, its mass increased, slid down the slope of the erosional niche. Also people contributed greatly to those transformations by their intensive use of the beach, especially on sunny and warm days, which was readily visible to the right of the little bridge where the analysed microform had appeared. The development of the erosional niche can be associated with easier access to water and lack of vegetation, and hence with greater plasticity of material and its susceptibility to sliding. The sliding of material, its accumulation at the foot of the slope, and its wash-out by lake water had led to a retreat of the margin of the lake terrace, mainly to the right of the little bridge, i.e. in the place where resistance to morphogenetic change is low while tourist traffic is heavy. The heavily washed and distorted ero- 
sional niche became more stable when August ended and September began, although it did not grow in size. This was due to the absence of precipitation, a drop in the water level and, because of the low diurnal air temperature, a shortage of recreation seekers.

The next summer season of 2009 also contributed to the present shape of the shore zone of Lake Czarne. June brought rainy weather, with rainfall exceeding $115 \mathrm{~mm}$ and the diurnal air temperatures ranging from 10 to $15^{\circ} \mathrm{C}$. July and August were similar: warm (ca. $25^{\circ} \mathrm{C}$ ), sunny days intertwined with colder rain spells of several days' duration. The intensity of precipitation was high, on a few occasions even up to $20 \mathrm{~mm}$. Torrential rains contributed to the cutting and development of the next erosional dissections, this time in the part of the shore zone jutting farthest into the water. Heavy rainfall released great potential energy in the landscape and set in motion large-scale denudation processes. Of basic significance for the modelling of the lakeshore relief was also the high stage of the lake water and groundwater. High soil moisture content combined with the erosional effect of waving caused the washing of not only the right-hand side of the shore zone, but also of the very unstable, strongly water-logged front part of the scarp. The material from the scarp zone slid completely in late August 2009 (Fig. 2d).

While the resistance of the geoecosystem of the Lake Czarne shore zone has been broken primarily in plant cover and soil, the most readily visible changes are those produced in the slope morphology by both, denudation and tourist use. Threshold values of slope processes depend on the physical properties of the covers, while the magnitude of their shift is connected with land use. What determines the impact of the various forms of tourism on the shore zone of Lake Czarne is their intensity, which depends primarily on the air temperature being above $25^{\circ} \mathrm{C}$ and the weather being sunny and calm. The interaction of the slope and shore processes in association with tourist use produced a change in the shape and inclination of the slope. The lower part of the shore zone became more gentle owing to the accumulation of material in the form of a talus cone, which can develop plant cover during the next season in favourable weather conditions, or be washed out if the water stage is high. Equilibrium in the shore zone of the lake was disturbed locally along its abrasion-prone sand-loam section subjected to the heaviest visitor traffic. In the four years of the study, its scarp retreated 10 to 50 $\mathrm{cm}$. The observed changes in the morphology of the shore zone are limited primarily to the lower part of the slope, at the contact with the lake terrace. According to Stach (1998), what make the morphological effects slight here are soil leaching, a considerable thickness of the aeration zone, and the associated large water capacity.

\section{Conclusions}

In the summer, changes in the shore zone of Lake Czarne depend on seasonal variations in weather conditions, mainly the pattern of precipitation and air temperature, and on seasonal vegetation growth. Those factors directly affect the intensity of relief-forming processes. The morphogenetic changes observed here in the years 2006-2009 would not be so intensive if it was not for tourist traffic. It should be emphasised, however, that the emergence and development of microforms genetically connected with tourist use are an effect of both, tourism and specific meteorological conditions. In terms of susceptibility to morphological change, the most detrimental is the following scenario: a few days of rainfall (of over $20 \mathrm{~mm}$ ) - a sudden jump in temperature to $25^{\circ} \mathrm{C}$ - a tourist capacity index in excess of 10 persons $/ 100 \mathrm{~m}^{2} /$ day. Several repetitions of this scenario enhance the probability of the appearance and development of man-made microforms. Hence, what is decisive for the dynamics of morphological change in the shore zone of the lake is the atmospheric situation on days preceding high tourist capacity.

\section{References}

BALON J., 1989. Wpływ taternictwa na morfologię ścian w Dolinie Gąsienicowej. Czasopismo Geograficzne LX: 17-30.

Balon J., German K., Maciejowski W. \& Ziaja W., 2001. Współczesne przemiany środowiska przyrodniczego i ich wpływ na funkcjonowanie Karpat Polskich. In: K. German, J. Balon (eds.), Przemiany środowiska przyrod- 
niczego Polski a jego funkcjonowanie. Problemy Ekologii Krajobrazu X: 553-560.

BANACH M., 1993. Degradacja brzegów zbiornika Włocławek. Przegląd Geograficzny 45, 1-2: 111-135.

BARANOWSKA-JANOTA M., 1998. Metoda określania chłonności turystycznej na przykładzie obszarów górskich województwa krośnieńskiego. Człowiek i Środowisko 22(1): 121-138.

BARTKOWSKI T., 1985. Metoda oceny przydatności do rekreacji linii brzegowej jezior. Sprawozdania PTPN za 1985, 104: 187-190.

Baud-Bovy M., 1977. Tourism and Recreational Development. The Architectural Press.

Brown K., Tuner R.K., Hameed H. \& Bateman J., 1997. Environmental carrying capacity and tourism development in the Maldives and Nepal. Environmental Conservation, 24,4 .

Buchwat A., 2009. Dendrogeomorphological records of trail erosion. In: Kaczka, Malik, Owczarek, Gärtner, Heinrich, Helle, Schleser (eds.), TRACE - Tree Rings in Archaeology. Climatology and Ecology, vol. 7. GFZ Potsdam, Scientific Technical Report STR 09/03, Potsdam: 166-170.

Cichoń M., 2008. Podatność na degradację stref brzegowych jezior Pomorza Środkowego. In: JekatierynczukRudczyk, Stiepaniuk, Mazur (eds.), Współczesne problemy badawcze geografii polskiej - geografia fizyczna. Dokumentacja Geograficzna 37: 62-67.

Drwal J. \& GoŁęBIEWSKI R., 1968. Próba klasyfikacji brzegów i niektóre procesy brzegowe Jeziora Raduńskiego. Zeszyty Geograficzne WSP w Gdańsku, R.X.WSP, Gdańsk: 185-197.

DRZEWIECKI M., 1997. Formy degradacji zbiorników wodnych $\mathrm{i}$ ich otoczenia $\mathrm{w}$ wyniku użytkowania rekreacyjnego. In: A. Choiński (ed.), Wptyw antropopresji na jeziora. Wyd. Homini, Poznań-Bydgoszcz: 20-25.

DYSARZ R., 1993. Charakter przeksztatceń środowiska geograficznego obszarów użytkowanych rekreacyjnie na wybranych przykładach w strefie pojezierzy. WSP, Bydgoszcz.

EWERTOWSKI M. \& TOMCZYK A., 2007. Ocena stanu środowiska geograficznego szlaków turystycznych - wykorzystanie GIS do integracji i analizy danych terenowych i kartograficznych. Przeglad Geograficzny 79: 271-295.

FLOREK W. (ed.), 2008. Rola procesów ekstremalnych w kształtowaniu rzeźby. Landform Analysis 8.

GorcZYCA E. \& KRZEMIEŃ K., 2002. Wpływ ruchu turystycznego na rzeźbę Tatrzańskiego Parku Narodowego. In: W. Borowiec et al. (eds.), Przemiany środowiska przyrodniczego Tatr. Kraków-Zakopane: 389-393.

GrobelsKa H., 2002. Strefa brzegowa Zbiornika Pakoskiego na Noteci Zachodniej - morfologia i osady platformy przybrzeżnej. Przegląd Geograficzny 74, 4: 547-567.

JaGuś A., 2004. Badania limnicznych procesów brzegowych w Polsce (zarys rozwoju i aspekty poznawczo-użytkowe). In: A.T. Jankowski, M. Rzętała (eds.), Jeziora i sztuczne zbiorniki wodne - funkcjonowanie, rewitalizacja $i$ ochrona. WNoZ UŚ, Sosnowiec: 77-86.

JoDŁOWSKI M., 2001. Antropogeniczne przemiany środowiska przyrodniczego Tatr pod wpływem turystyki. In: K. German, J. Balon (eds.), Przemiany środowiska przyrodniczego Polski a jego funkcjonowanie. Problemy Ekologii Krajobrazu X: 796-803.

KARCZEWSKI A., 1989. Morfogeneza strefy marginalnej fazy pomorskiej na obszarze lobu Parsęty w vistulianie (Pomorze Środkowe). Wyd. Naukowe UAM, seria Geografia 44, Poznań.
KLIMKO R., 1982. Przeksztatcenia funkcjonalne geokompleksów w aspekcie procesów denudacyjnych $i$ wodno-wilgotnościowych na dolna Warta i Obrą. Wyd. Naukowe UAM, seria Geografia 27, Poznań.

Korolec H., 1968. Procesy brzegowe i zmiany linii brzegowej Jeziora Mikołajskiego. Prace Geograficzne Instytutu Geografii PAN 73.

KostrZewski A., KlimcZak R., StACh A. \& Zwoliński Z., 1992. Extreme rainfalls and their influence on functioning of the present-day denudative system in a young glaciall region. West Pomerania. Questiones Geographicae, special issue, 3: 97-113.

KostrZewSKi A., 1999. Funkcjonowanie geoekosystemów zlewni rzecznych przymorza Bałtyku w warunkach wezbraniowych i powodziowych - propozycje programowe. In: A. Kostrzewski (ed.), Funkcjonowanie geoekosystemów zlewni rzecznych. Powodzie rzek przymorza Battyku i innych regionów Polski. Uwarunkowania, przebieg, skutki w środowisku przyrodniczym. T. 2. Bogucki Wydawnictwo Naukowe, Poznań: 11-15.

Kostrzewski A., 2008. Present state and functioning of lake geoecosystem - methodological and methodical assumptions. Limnological Review 8, 1-2: 5-8.

ŁAJCZAK A., 1996. Wpływ narciarstwa i turystyki pieszej na erozję gleby na obszarze podszczytowym Pilska. In: Wpływ narciarstwa i turystyki pieszej na przyrodę Masywu Pilska. Studia Naturae 41: 131-159. PAN, Instytut Ochrony Przyrody, Kraków.

NowaczyK B., 1994. Jezioro Gacno Wielkie i Gacno Małe krótkoterminowe wahania poziomu jezior i ich efekty morfologiczne. In: B. Nowaczyk (ed.), Warsztaty terenowe "Geomorfologia i osady strefy litoralnej jezior", Charzykowy. IBCz UAM, KBCz PAN, Poznań.

OsTENDORP W., 2004. New approaches to integrated quality assessment of lakeshores. Limnologica 34, 1-2: 160-166.

PRATO T., 2001. Modeling carrying capacity for national parks. Ecological Economics 39.

RYHÄNEN H., 2001. The touristic profile and potential of European lake destinations. International Conference 4-6 October, Dublin: 1-15.

RzĘTAŁA M., 1994. Klasyfikacja wybrzeży i procesy brzegowe wybranych zbiorników antropogenicznych Kotliny Dąbrowskiej. In: Ksztattowanie środowiska geograficznego $i$ ochrona przyrody na obszarach uprzemystowionych $i$ zurbanizowanych 14. WBiOŚ, WNoZ UŚ, Katowice-Sosnowiec: 29-37.

SCHMIEDER K., 2005. European lake shores in danger - concepts for a sustainable development. Limnologica 37, 2.

SKAwiŃSKI P. \& KRZAN Z., 1996. Narciarstwo. In: Z. Mirek (ed.), Przyroda Tatrzańskiego Parku Narodowego. Tatrzański Park Narodowy, Kraków-Zakopane: 697-716.

SoŁowiej D., KozŁowsKa M. \& SĄSIADeK W., 1997. Identyfikacja konfliktów człowiek-środowisko przyrodnicze w jeziornych systemach rekreacyjnych. In: A. Choiński (ed.), Wptyw antropopresji na jeziora. Wyd. Homini, PoznańBydgoszcz: 152-160.

SтAсн A., 1998. Obieg wody i procesy denudacyjne a kateny glebowe na stokach młodoglacjalnych. In: K. Pękala (ed.), Główne kierunki badań geomorfologicznych w Polsce. Stan aktualny i perspektywy. T. I. Wydawnictwo UMCS, Lublin: 177-179.

Starkel L., 2008. Procesy stokowe i fluwialne przekształcające rzeźbę - czy model z lat 70. jest nadal aktualny? Landform Analysis 9: 16-20. 
STYPEREK J., 2001. Piesze szlaki turystyczne w polskich parkach narodowych. Turyzm 11, 1: 25-37.

ZwOLIŃSKI A., 1992. Ocena walorów turystyczno-rekreacyjnych sztucznych zbiorników wodnych (na przykładzie zbiorników nizinnych). Instytut Turystyki.
ZwOLIŃSKI Z., 2008. Wybrane zjawiska ekstremalne pojezierzy polskich. Lanform Analysis 8: 98-106. 